\title{
KEAMANAN DALAM TINDAKAN ANESTESIA
}

\author{
Magdalena F. Sakliressy \\ Lucky T. Kumaat \\ Antje A. Wuwungan
}

\author{
Bagian Anestesi Fakultas Kedokteran Universitas Sam Ratulangi Manado \\ Email: Fanny_imel@yahoo.co.id
}

\begin{abstract}
In general, anaesthetic means an act of relieving pain during surgery and or other procedures that cause pain in the body. In all anaesthetic procedures safety is of most concern, including the reduction of any risks of danger or related complications that can happen during anaesthesia. Understanding about the stages of anasthesia from pre-anesthesia until post-anasthesia, as well as techniques of anasthesia, is very important in creating the anaesthesia safety.
\end{abstract}

Key words: safety, anaesthetic, anaesthesia, patient

\begin{abstract}
Abstrak: Secara umum, anestesia berarti suatu tindakan menghilangkan rasa nyeri saat melakukan pembedahan dan atau berbagai prosedur lainnya yang menimbulkan rasa nyeri pada tubuh. Dalam setiap tindakan anestesia harus diperhatikan segi keamanannya. Pemahaman mengenai tahap-tahap anaestesia sejak pre anestesia sampai dengan pasca anestesia serta tehnik-tehnik anestesia sangat diperlukan untuk mencapai keamanan dalam tindakan anestesia
\end{abstract}

Kata Kunci: keamanan, tindakan, anestesia, pasien

Keamanan dalam tindakan anestesia (anaesthesia safety) merupakan suatu masalah penting yang harus diperhatikan secara serius sejak saat pra operatif hingga pasca operatif. Tindakan ini bertujuan untuk mengurangi bahaya atau risiko buruk yang dapat terjadi pada saat pasca anestesia.

Dengan mengutamakan keamanan dalam tindakan anestesia berarti keselamatan pasien (patient safety) juga turut diutamakan. Menurut Institute of Medicine, keselamatan pasien didefinisikan sebagai freedom from accidental injury. Secara umum, accidental injury disebabkan karena kesalahan yang meliputi kegagalan suatu perencanaan atau menggunakan rencana yang salah untuk mencapai tujuan. Accidental injury juga merupakan akibat dari melaksanakan suatu tindakan atau tidak mengambil tindakan yang seharusnya diambil. Tujuan patient safety ialah untuk mengurangi risiko cedera pada pasien akibat struktur dan proses pelayanan kesehatan. ${ }^{4,5}$

Risiko dari kurangnya perhatian terhadap anaesthesia safety pada suatu tindakan operatif dapat menimbulkan masalah antara lain kesalahan memilih obat yang tepat, kesalahan memilih sirkuit anestesia, tidak terdeteksinya gangguan koneksi alat-alat, kesalahan dalam intubasi esofagus dan intubasi bronkial, ekstubasi terlalu dini, ventilasi buatan kurang adekuat, dan sebagainya. ${ }^{2}$

Beberapa studi mengemukakan bahwa persentasi risiko kematian akibat anestesia relatif kecil, tetapi catatan dari para ahli menyatakan adanya kematian yang terjadi akibat anestesia. Berdasarkan hal ini maka keamanan dalam tindakan anestesia perlu diperhatikan untuk mengurangi angka kejadian serta faktor risiko yang dapat menyebabkan kematian. 


\section{DEFINISI}

Anaesthesia safety merupakan keamanan dalam tindakan anestesia terhadap pasien secara menyeluruh mulai dari penilaian dan persiapan pra anestesia, anestesia hingga pasca anestesia. Untuk itu, dibutuhkan pemahaman yang menyeluruh tentang prinsipprinsip anestesia pada saat pemantauan dan parameter tingkat kesadaran normal dan abnormal pada pasien. Morton dan Wylie (1951) mengemukakan bahwa sebagian besar kematian pada waktu anestesia diakibatkan oleh kurangnya pengalaman dan kegagalan dalam melakukan tindakan pencegahan saat intubasi. ${ }^{4}$ Hal ini meliputi kecelakaan akibat intubasi, misalnya pengeluaran aspirasi, kekakuan pipa trakea dan bronkoskopi; masing-masing mungkin mengakibatkan hambatan vagal jika pernafasan dari anestesia tidak adekuat. Penyumbatan pernafasan setelah operasi dengan pipa trakea mungkin juga dapat terjadi. ${ }^{6}$ Dengan demikian, untuk mencegah terjadinya berbagai hal yang tidak diinginkan, perlu adanya prosedur keamanan yang dilakukan pada pra anestesi hingga pasca anestesi

\section{KLASIFIKASI}

American Society of Anesthesiologists (ASA) menyusun klasifikasi status fisik pasien pra anestesia atas enam kelas, yaitu: ${ }^{1-3}$

Kelas I: Pasien sehat organik, fisiologik, psikiatrik, biokimiawi.

Kelas II: Pasien dengan penyakit sistemik ringan atau sedang.

Kelas III: Pasien dengan penyakit sistemik berat sehinga aktivitas rutin terbatas.

Kelas IV: Pasien dengan penyakit sistemik berat, tidak dapat melakukan aktivitas rutin, dan penyakitnya merupakan ancaman kehidupan setiap saat.

Kelas V: Pasien sekarat yang diperkirakan dengan atau tanpa pembedahan hidupnya tidak akan lebih dari 24 jam. $^{1-3}$

Kelas E: Bila tindakan pembedahan dilakukan secara darurat, dicantumkan tanda $\mathrm{E}$ (emergency) di belakang angka.

\section{KEAMANAN DALAM TINDAKAN ANESTESIA}

\section{Pra anestesia}

\section{Evaluasi waktu dan tatalaksana}

Pra anestesia merupakan langkah awal dari rangkaian tindakan anestesia yang dilakuakan terhadap pasien yang direncanakan untuk menjalani tindakan operatif. Hal-hal yang perlu dilakukan meliputi anamnesis, pemeriksaan fisik, pemeriksaan laboratorium, dan klasifikasi status fisik. ${ }^{1-3}$ Persiapan dilakukan di poliklinik atau di rumah untuk pasien rawat jalan, di ruang perawatan, di ruang Instalasi Bedah Sentral (IBS), dan di kamar operasi. ${ }^{1}$

Berbagai faktor harus dipertimbangkan untuk pemberian anestesia-analgesia kepada pasien, antara lain: umur, jenis kelamin, status fisik, jenis operasi, ketrampilan operator dan peralatan yang dipakai, ketrampilan dan kemampuan pelaksanaan anestesia, sarana, status rumah sakit, dan permintaan pasien. ${ }^{1}$

\section{Peri anestesia}

Dalam praktek anestesia, terdapat tiga jenis anestesia-analgesia yang diberikan pada pasien yang akan menjalani pembedahan yaitu: anestesia umum, anestesia lokal, dan anestesia regional. ${ }^{1-4}$

\section{Pemantauan (monitoring)}

Tujuan utama yaitu mendiagnosis adanya permasalahan, perkiraan kemungkinan terjadinya kegawatan, serta evaluasi hasil suatu tindakan, termasuk efek samping. Pemantauan pada saat perianestesia dibagi atas dua bagian yaitu: pemantauan alat anestesia dan pemantauan pasien.

Pemantauan alat anestesia meliputi pengecekan aliran listrik apakah telah terpasang baik pada mesin anestesia serta telah diaktifkan; alat monitoring anestesia yang berfungsi sebagai parameter keadaan pasien; aliran gas pada pipa telah terpasang dengan benar dan bebas dari obstruksi/ penyumbatan; peralatan anestesia apakah telah terhubung pada suplai oksigen; suplai 
oksigen cadangan yang cukup telah tersedia pada tabung vapour analyser (mudah menguap apabila tidak tersambung rapat dan benar); peralatan infus telah terpasang dengan benar dan aman serta telah diseting dengan benar dan dapat didengar. ${ }^{1,2,8}$

Pemantauan terhadap pasien meliputi pemantauan jalan nafas, oksigenasi, ventilasi, sirkulasi, serta suhu badan. ${ }^{1,2,8}$

\section{Pasca anestesia/pasca operatif}

Pasca anestesia merupakan periode kritis yang segera dimulai setelah pembedahan dan anestesia diakhiri sampai pasien pulih dari pengaruh anestesia.

Pemindahan pasien dari kamar operasi dilaksanakan dengan hati-hati mengingat pasien dalam keadaan belum sadar penuh atau belum pulih dari pengaruh anestesia. Posisi kepala diatur sedemikian rupa sehingga keluasan jalan nafas tetap adekuat dan ventilasi terjamin. Pada pasien yang belum bernafas spontan, diberikan nafas buatan. Gerakan pada saat memindahkan pasien dapat menimbulkan atau menambah rasa nyeri akibat tindakan pembedahan dan bisa terjadi dislokasi sendi. Pada pasien dengan blok spinal, posisi pasien diatur sedemikian rupa sehingga aliran darah dari daerah tungkai ke proksimal tetap lancar; infus, pipa nasogastrik, dan kateter urin harus tetap berfungsi dengan baik atau tidak terlepas. ${ }^{1}$

\section{Pasca operatif di ruang pulih unit pera- watan pasca anestesia (UPPA)}

Pasien pulih dari anestesia secara rutin dikelola di UPPA (Recovery Room/RR, Pra anestesia Care Unit/PACU). Idealnya, pada saat pasien bangun dari anestesia terjadi secara bertahap, tanpa keluhan, dan berjalan baik. Perlu dicegah dan dihindari hal-hal yang mungkin terjadi akibat stres pasca bedah atau pasca anestesia yaitu berupa gangguan napas, gangguan kardiovaskular, gelisah, nyeri, mual-muntah, menggigil, dan kadang-kadang perdarahan. ${ }^{2}$

\section{SIMPULAN}

Keamanan dalam tindakan anestesia secara keseluruhan meliputi penilaian dan persiapan pra anestesia hingga pasca anestesia. Tindakan ini bertujuan untuk mengurangi bahaya atau risiko buruk yang dapat terjadi pada saat pasca anestesia. Pemahaman tentang tahap-tahap persiapan pra anestesia hingga pasca anestesia, serta teknik-teknik pelaksanan anestesia perlu dipahami untuk mencapai keamanan dalam tindakan anestesia.

\section{DAFTAR PUSTAKA}

1. Mangku G, Senapathi TGA. Ilmu Anestesia dan Reanimasi. Jakarta: Permata Puri Media, 2009; p.87-88.

2. Latief SA, Surjadi K. Dachlan RM. Petunjuk Praktis Anestesialogi (Edisi Kedua). Jakarta: Bagian Anestesiologi FKUI, 2001; p.29-31.

3. Wrobel M, Werth M. Pokok-Pokok Anestesia. Jakarta: EGC, 2009; p.23.

4. Pinzon R. Konsep dasar patient safety dalam pelayanan kesehatan. Berkala Ilmiah Kesehatan Fatmawati. 2006;7(18):738742.

5. Bambang J. Belajar kenal dengan program keselamatan pasien (patien safety). [homepage on the Internet] 2010 [update Jun 2010; cited 2011 Nov 09]. Available from http://ihqn.or.id/wpcontent/ uploads/2010/06/proposalbreakthrough. pdf.

6. Vanessa IDA. Kematian akibat anestesia [homepage on the Internet]. 2009 [update 2009 Feb 22; cited 2011 Nov12]. Available from: http://paperforensik-fkunram.blogspot. com/2009/02/kematian-akibatanestesia.html 